\title{
LA PERSONALIDAD JURÍdICA DE LA IGLESIA CATÓliCA DESPUÉS DE LA CONSTITUCIÓN DE 1925 EN LOS INFORMES DEL NUNCIO ETTORE FELICI AL CARDENAL SECRETARIO DE ESTADO DEL VATICANO: 1928-1932: ENTRE LA ADAPTACIÓN Y LA INADAPTACIÓN DE CHILE A LA LIBERTAD DE CULTOS*
}

\section{Carlos Salinas ARaneda**}

RESUMEN: A partir de documentación del Archivo Secreto Vaticano recientemente desclasificada, se estudian los esfuerzos del nuncio Ettore Felici por asegurar la personalidad jurídica de derecho público de la Iglesia Católica en Chile después de la entrada en vigencia de la Constitución de 1925, esfuerzos de los que dan cuenta los informes enviados a sus superiores vaticanos con ocasión de sus intentos por obtener la firma de un concordato. En su archivo se encuentran, además, informes de juristas y eclesiásticos, que muestran el interés del diplomático por respaldar sus esfuerzos con argumentos serios. El estudio se complementa con documentos del Ministerio de Relaciones Exteriores que muestran la visión del ministerio sobre la actuación del nuncio en esta materia, en momentos en que el gobierno de Chile muestra una cierta inadaptación frente a la nueva realidad constitucional de libertad de cultos.

PALABRAS CLAVE: Personalidad jurídica de la Iglesia Católica - nuncio Ettore Felici - concordato - Arturo Alessandri Rodríguez.

\footnotetext{
* Este artículo forma parte del proyecto Fondecyt regular 1140891 del que el autor es investigador responsable.

Fecha de recepción: 28 de septiembre de 2015.

Fecha de aceptación: 11 de enero de 2016.

** Doctor en Derecho por la Universidad Complutense de Madrid (España); Doctor en Derecho Canónico por la Pontificia Universidad Santo Tomas in Urbe, Angelicum (Italia). Catedrático de Historia del Derecho y de Derecho Canónico en la Pontificia Universidad Católica de Valparaíso (CHILE). Correo electrónico: csalinas@ucv.cl
} 


\title{
The legal status of The CaTholic CHurCH AFTer THE 1925's CONSTITUTION, ACCORDING TO THE REPORTS OF THE NUNTIUS ETTORE FELICI TO THE CARDINAL SECRETARY OF THE VATICAN STATE: 1928-1932: \\ BETWEEN THE ADAPTATION AND MALADJUSTMENT TO FREE- DOM OF WORSHIP IN CHILE
}

\begin{abstract}
This paper takes from a research conducted in the secret archives of the Vatican - recently declassified. The paper analyses the efforts made by the Nuntius Ettore Felici to keep the public legal entity of the Catholic Church after the enactment of the 1925's Chilean Constitution. Those efforts reveal the reports sent to their superiors in the Vatican, on occasion of his attempts to obtain the signature of a concordat. In addition, it is possible to find in his archives reports coming from legal scholars and members of the ecclesiastical body, which show his interest to support his view on solid foundations. Furthermore, the research takes into account documents coming from the Ministry of Foreign Affairs, which show its view on the conduct of the Nuntius related to this issue, just in a moment when the Chilean government showed a hesitant behaviour towards the new constitutional order regarding freedom of worship.
\end{abstract}

KEYWORDS: Legal Status of the Catholic Church - Nuntius Ettore Felici - Concordat - Arturo Alessandri Rodríguez

Sumario: Introducción. 1) La personalidad jurídica de la Iglesia en los proyectos de concordato de 1928. (1.1.) Pio XI y la nueva era de los concordatos. (1.2.) Las gestiones del nuncio. (1.3.) Los proyectos de concordato del gobierno de Chile. (1.4.) El contraproyecto del nuncio. 2) Las nuevas preocupaciones del nuncio. 3) Otras opiniones sobre la personalidad juridica de la Iglesia. (3.1.) Juristas. (3.1.1.) Arturo Alessandri Rodríguez, decano de la Facultad de Derecho de la Universidad de Chile: personalidad juridica de derecho público antes y después de la Constitución de 1925, pero sometida al derecho común respecto de los bienes adquiridos después de la misma. (3.1.2.) Otra opinión en la linea de Alessandri: personalidad juridica de derecho público antes y después de la Constitución de 1925, pero sometida al derecho común respecto de los bienes adquiridos después de la misma. (3.1.3.) Romualdo Silva: persona juridica de derecho constitucional con características de la personalidad de derecho público. (3.1.4.) Miguel L. Valdés, una opinión disidente: la Iglesia debe organizarse como persona juridica de derecho privado-corporaciones y fundaciones-a partir de la nueva Constitución. (3.2.) Eclesiásticos. (3.2.1.) Rafael Edwards Salas, obispo auxiliar de Santiago y vicario castrense de Chile: la Iglesia persona de derecho constitucional. (3.2.2.) 
Gilberto Fuenzalida Guzmán, obispo de Concepción: obtener del gobierno el derecho para el dominio de los bienes adquiridos después de 1925. (3.2.3.) Aloisi Masella, nuncio apostólico en Chile entre 1919 y 1927: mientras no se reformare el artículo 547 del Código Civil, la Iglesia continuaría siendo una persona jurídica de derecho público y por consiguiente dichas disposiciones no le serian aplicables. 4) El gobierno de Chile y la personalidad jurídica de la Iglesia en la correspondencia del Ministerio de Relaciones Exteriores. Conclusiones. Bibliografía citada.

\section{INTRODUCCIÓN}

El 2 de enero de 1928 presentó sus credenciales ante el Presidente de la República, Carlos Ibáñez del Campo, como nuncio del papa Pío XI ante el gobierno de Chile, Ettore Felici Faggiolo. Había nacido en Segni, Italia, el 12 de marzo de 1881, por lo que asumía sus funciones diplomáticas en nuestra patria a pocas semanas de cumplir 47 ańos. Después de sus estudios sacerdotales en su ciudad natal, había obtenido en Roma el doctorado en teología, en filosofía y en derecho canónico. Era, pues, un diplomático que se movía con soltura en el mundo del derecho.

$\mathrm{Su}$ nombramiento como nuncio en Chile era el primero en su carrera diplomática, pero nuestra patria no le era desconocida pues antes había prestado sus servicios en la nunciatura chilena y en ella se desempeñaba cuando llegó su nombramiento para reemplazar al nuncio anterior, Benedetto Aloisi Masella, quien había llevado adelante, en nombre de la Santa Sede, las conversaciones tendentes a obtener la amigable separación de la Iglesia y el Estado en Chile, quien había sido nombrado nuncio en Brasil. Precisamente fue en Santiago de Chile donde Ettore Felici, el 30 de diciembre de 1927, es decir, tres días antes de presentar sus credenciales, había sido consagrado arzobispo titular de Corinto, pues, para desempeñar su nuevo cargo diplomático, requería de la calidad arzobispal.

Entre las instrucciones que tenía el nuevo representante diplomático vaticano estaba la de gestionar la firma de un concordato entre Chile y la Santa Sede. Son los concordatos acuerdos internacionales con rango de tratados internacionales firmados por la Santa Sede y los gobiernos de los Estados, con la finalidad de regular aquellas materias en las que el poder temporal y el poder espiritual tienen interés común. En la nueva Constitución que había entrado en vigencia el 18 de octubre de 1925, estaba expresamente contemplado en su artículo 72, entre las atribuciones especiales del Presidente de la República, "mantener las relaciones políticas con las potencias extranjeras, recibir sus agentes, admitir sus cónsules, conducir las negociaciones, hacer las estipulaciones preliminares, concluir y firmar todos los tratados de paz, de alianza, de tregua, de neutralidad, de comercio, concordatos y otras convenciones" (art. 72 no 16 i.p.). 
La Constitución de 1925 había inaugurado una nueva etapa en las relaciones entre el Estado y la Iglesia, pues había consagrado la libertad de cultos, dando origen, por primera vez en Chile, a la separación entre el poder temporal y el espiritual. Esta nueva realidad significó para las autoridades temporales perder una serie de atribuciones que les otorgaba la Constitución de 1833 en relación con la Iglesia Católica, concentradas todas ellas en la institución del patronato. Las gestiones iniciadas por el nuncio para cumplir las instrucciones recibidas en Roma ofrecieron a las autoridades chilenas la ocasión para revisar esta nueva realidad e intentar recuperar, al menos en parte, alguna intervención al interior de la Iglesia, evidenciando en las autoridades chilenas una cierta inadaptación a la nueva realidad constitucional en lo que a los asuntos religiosos se refiere, regida ahora por el principio de libertad de cultos.

En efecto, el derecho de patronato consagrado unilateralmente por la Constitución Política de 1833, había dado a las autoridades chilenas la posibilidad de intervenir en asuntos internos de la Iglesia, tales como el nombramiento de obispos, controlar los documentos llegados desde Roma mediante el plácet o antiguo pase regio, autorizar la creación de nuevas diócesis, y otros derechos que con la nueva Constitución de 1925 quedaron por completo derogados. Las gestiones iniciadas por el nuncio en orden a obtener la firma de un concordato, facilitaba a las autoridades chilenas una vía para recuperar, al menos en parte, algunos de los derechos perdidos, siendo el más importante de todos, obtener alguna intervención en el nombramiento de los obispos. Esta actitud mostraba en las autoridades chilenas cierta inadaptación a las nuevas realidades porque, mientras, por una parte, ellas habían buscado la separación del Estado y la Iglesia, por otra, no del todo satisfechas con algunas de las consecuencias que había traído dicha separación, intentaron recuperar parte de las prerrogativas que la nueva Constitución había dejado de lado.

Uno de los temas que desde el primer momento centró la atención de las dos partes fue el de la personalidad jurídica de la Iglesia, tema de suficiente entidad como para que se transformara en la piedra de toque que, finalmente, terminó por impedir que la iniciativa diplomática fructificara en la firma de un concordato entre Chile y la Santa Sede.

\section{1) LA PERSONALIDAd JURídica DE LA IGLESIA EN LOS PROYeCTOS DE CONCORDATO DE 1928}

\section{(1.1.) Pío XI Y La NUEVA ERA DE LOS CONCORDATOS}

Este interés de la Santa Sede se situaba en una nueva política internacional que había empezado a llevar adelante el papa Pío XI, quien había accedido al trono pontificio el 6 de febrero de 1922, cuando aún estaba pendiente la llamada "cuestión romana", originada con la invasión 
y posterior desaparición de los Estados Pontificios y el establecimiento del reino de Italia, cuya culminación se produciría en 1929 con la firma de los pactos de Letrán que, entre otras cosas, darían origen al Estado de la Ciudad del Vaticano. Al finalizar la primera Guerra Mundial el panorama geográfico europeo había quedado modificado con la aparición de nuevos Estados independientes y el cambio no menor de las fronteras de otros, lo que había dado origen a un nuevo impulso en la celebración de concordatos por el nuevo pontífice quien, precisamente por esta circunstancia, en más de una ocasión ha sido llamado el Papa de los concordatos ${ }^{1}$.

La "nueva era de los concordatos" se había iniciado en 1922 con el concordato con el Gobierno de Letonia, firmado el 30 de mayo de ese año $^{3}$. Su independencia se había declarado el 18 de noviembre de 1918 y fue reconocida por los soviets en 1920. En 1922 se había dotado de una Constitución democrática que no decía palabra alguna sobre lo religioso, no obstante lo cual celebró un concordato que, al parecer, fue visto por sus autoridades como un medio de reconocimiento internacional ${ }^{4}$. Si bien contaba solo con una minoría de católicos, el concordato se abría con un artículo que garantizaba a la religión Católica su ejercicio libre y público, además que se le reconocía "la personalidad jurídica con todos los derechos que el Código Civil de Letonia reconoce a las otras personas civiles" (art. 1). Es decir, no menos, pero no más que los derechos de una persona jurídica de derecho privado. Un nuevo concordato fue celebrado en 1925 entre la Santa Sede y la República de Polonia, el 10 de febrero de $1925^{5}$. Su Constitución parlamentaria había previsto en 1921 que las relaciones con la Iglesia Católica serían reguladas por un concordato, pero hubo que esperar hasta que finalizaran las discusiones acerca de sus fronteras para firmar el concordato. En diversos artículos de este se alude y reconoce a las "personas juridicas eclesiásticas y religiosas" y se les reconoce el derecho de adquirir, poseer, administrar y ceder bienes, pero ello lo han de hacer conforme al "derecho común del Estado", sin que en parte alguna se les reconozca la calidad de personas jurídicas de derecho público.

En 1927, es decir el año inmediatamente anterior a la presentación de credenciales por el nuncio Felici, fueron dos concordatos y un modus vivendi los celebrados por la Santa Sede. El primero de los concordatos

\footnotetext{
1 Stella, Giordano (2009) Pio XI il Papa dei concordati. Milano: Gribaudi Editore, 240 pp., pp. 112-147.

2 De la Brière, Y. (1942) “Les concordats postérieurs à la Grande Guerre”. En Dictionnaire de droit Canonique. Paris: Tomo III, cols. 1431-1472; Minnerath, Roland (2012) L'Église catolique face aux États. Deux siècles de pratique concordataire 1801-2010. Paris: Les Éditios du Cerf, 650 pp., pp. 61-75.

3 Su texto en Enchiridion dei concordati. Due secoli di Storia dei Rapporti Chiesa-Stato (2003). Bologna: Dehoniane, 2257 pp., pp. 590-597.

4 Minnerath (2012) 64-65.

5 Su texto en Enchiridion (2003) 654-675.
} 
fue celebrado con el Reino de Rumanía, el 10 de mayo de 19276; era Rumanía un reino multiétnico y multiconfesional, con una población ortodoxa que alcanzaba el 70\%; los rumanos uniatas, es decir, ortodoxos que habían vuelto a unirse a Roma, eran apenas el 10\% de la población y aunque se les aseguraba una posición oficial, las leyes les apremiaban a volver a la ortodoxia. Se reconocían en su articulado las "personas jurídicas eclesiásticas y religiosas" pero no se les reconoce personalidad jurídica de derecho público. El 27 de septiembre del mismo año se celebró el concordato entre la Santa Sede y el Gobierno de Lituania7. Este Estado báltico había nacido a la vida independiente en 1918, al desmembrarse el imperio de los zares. Se trata de un concordato que siguió de cerca al concordato con Polonia, al punto que en ocasiones se transcriben textualmente algunos artículos. La mayoría de sus ciudadanos eran católicos y aunque el concordato reconocía a la Iglesia un rol social importante, como llevar los registros del estado civil de las personas o controlar las escuelas confesionales, en materia de bienes dispuso que "todas las personas jurídicas eclesiásticas y religiosas tienen, según las reglas del derecho común, el derecho de adquirir, ceder, poseer y administrar, conforme al derecho canónico, sus bienes muebles e inmuebles, asi como el derecho de comparecer ante todas las instancias o autoridades del Estado para la defensa de sus derechos civiles" (art. XVII). En materia patrimonial, pues, las personas jurídicas canónicas tenían la capacidad que el derecho común les otorgaba y para nada se aludía a una posible personalidad jurídica de derecho público ${ }^{8}$.

Los anteriores son los concordatos que me interesan porque ellos, con exclusión del modus vivendi celebrado con la República Checoslovaca el 17 de diciembre de 1927, fueron utilizados como modelos para la redacción de los proyectos de concordato a los que me he de referir 9 .

Su texto en Enchiridion (2003) 680-699.

Su texto en Enchiridion (2003) 698-711.

Minnerath (2012) 63-64.

No fueron los únicos acuerdos internacionales celebrados por la Santa Sede en los primeros años del pontificado de Pío XI que son los años inmediatamente anteriores a la redacción de los proyectos chilenos. A los anteriores hay que agregar el intercambio de notas y la convención con Colombia para la interpretación del artículo 17 del concordato (1923-1924, su texto en Enchiridion (2003) 596-615); el concordato entre la Santa Sede y el Estado de Baviera, Alemania (1924, su texto en Enchiridion (2003) 626-643); el intercambio de notas entre la Secretaría de Estado y el Consejo de Estado del Cantón de Friburgo, en Suiza (1924, su texto en Enchiridion (2003) 642-655); los acuerdos entre la Santa Sede y Francia acerca de los honores litúrgicos en los países donde se ejerce el protectorado religioso francés o en los países donde las capitulaciones están abrogadas o no se aplican (1926, su texto en Enchiridion (2003) 674-681); que en nada interesan a este estudio; y el acuerdo entre la Santa Sede y el Gobierno de Portugal para actualizar algunos aspectos del concordato de 1886 (1928, su texto en Enchiridion (2003) 716-721) que se firmaba el 15 de abril de 1928, es decir, pocos días antes de la presentación de los proyectos chilenos. Salvo el concordato con Baviera que sirvió de antecedente en algún punto de los proyectos chilenos, ninguno de los otros tuvo mayor incidencia en los proyectos chilenos. Ya por lo específico de las mate- 


\section{(1.2.) LAS GESTIONES DEL NUNCIO}

El nuncio se entregó de inmediato a la tarea de gestionar un concordato entre Chile y la Santa Sede, por lo que en un informe al cardenal secretario de Estado Vaticano fechado en Santiago, el 15 de marzo de 1927, le manifestaba que "conforme a las instrucciones que me fueron dadas antes de mi partida de Roma, no he faltado en reclamar discretamente la atención del gobierno sobre la oportunidad de un concordato"10. Agregaba el nuncio que las conversaciones que sobre la materia había tenido con diversos miembros del gabinete parecía que estaban dando resultado, al punto que el ministro de Relaciones Exteriores, don Conrado Ríos Gallardo, le había comunicado en la última audiencia que tenía redactado un proyecto de concordato del que, una vez que obtuviera la aprobación del Presidente de la República, don Carlos Ibáñez del Campo, le enviaría una copia para conocer su parecer. Más aun, el mismo día el subsecretario de dicho ministerio, que había tenido oportunidad de leerlo, le había manifestado que "salvo ligeras modificaciones", el proyecto seguía el texto del concordato que, poco antes, en octubre del año anterior, es decir, apenas tres meses antes que Felici iniciara sus tareas diplomáticas en Chile, se había concluido con Lituania"11, "texto que me ha parecido bien dar a conocer al ministro -decía el nuncio- para animarlo a seguir el ejemplo de la joven república" 12 .

Ahora bien, como lo he dicho, el concordato con Lituania siguió de cerca el concordato que el 10 de febrero de 1925 había celebrado la Santa Sede con la República de Polonia, concordato que también fue tenido a la vista por las autoridades chilenas, pues fueron ambos concordatos los que inspiraron la redacción de los proyectos de concordato chilenos.

\section{(1.3.) LOS PROYECTOS DE CONCORDATO DEL GOBIERNO DE CHILE}

El martes 1 de mayo de 1928, el embajador de Chile ante la Santa Sede, Ramón Subercaseaux, hizo entrega de un proyecto de concordato, diciendo que tenía instrucciones de pedir el parecer de la Secretaría de Es-

rias reguladas, ya porque es muy probable que su texto, como el portugués, no hubiese sido conocido en Chile al tiempo de la redacción de sus proyectos.

10 "Conformemente alle istruzioni datemi prima della mia partenza da Roma, non ho mancato di richiamare discretamente l'attenzione del Governo su la opportunità di un concordato". ARCHIvio Segreto Vaticano (= ASV), Sacra Congregazione degli Affari Ecclesiastici Straordinari (= AES), Cile 1927-1928. Pos. 283-285 PO. Fasc. 47.

11 Véase antes nota 7.

12 "Salvo leggere modificazioni, il testo del concordato testé concluso con la Lituania, testo que avevo creduto bene portare a conoscenza del ministro, per incoraggiarlo a seguire l'esempio della giovane repubblica”. ASV., AES, Cile 1927-1928. Pos. 283-285 PO. Fasc. 47. 
tado y que regresaría el viernes siguiente a recibir la respuesta ${ }^{13}$. Este proyecto no fue conocido por el nuncio, pero en la materia que me interesa, es idéntico a un segundo proyecto de concordato presentado por el ministro de Relaciones Exteriores al nuncio en Santiago algunos días después.

Según el artículo 1 de estos proyectos, "La Iglesia Católica gozará en el territorio de la República de Chile de plena libertad y podrá erigir y conservar templos y sus dependencias con las condiciones de seguridad e higiene fijadas por las leyes y ordenanzas que rijen [sic] en Chile sobre la materia". Se trata de una norma que, con diversas fórmulas, se encuentra en los concordatos celebrados en estos años, en concreto Letonia (1922, art. I), Baviera (1924, art. 1), Rumanía (1927, art. I) y Lituania (1927, art. I), si bien la fórmula que parece utilizada como inspiradora de este artículo en los dos proyectos chilenos, es la que se encuentra en el concordato celebrado con Polonia en $1925^{14}$, al que sigue de cerca el concordato con Lituania (1927, art. I). Pero dichas normas concordatarias, en sus textos originales conformaban un solo artículo, en tanto que en los proyectos chilenos había dado origen a los dos primeros artículos de estos textos. Así, el artículo 2 disponía: "El Gobierno de Chile asegura a la Iglesia y a los organismos que de ella dependen el libre ejercicio de su poder espiritual y de su jurisdicción eclesiástica, lo mismo que la libre administración de sus bienes y negocios, conforme al derecho canónico en cuanto no se oponga a las leyes chilenas" 15 .

En ninguno de ambos artículos, ni en ninguno de los que les seguían, se hacía alusión a la personalidad jurídica de la Iglesia, aunque en un artículo posterior, el artículo 20, se disponía que "conforme a la legislación chilena, las iglesias, los ordinarios, las parroquias y las comunidades religiosas legalmente establecidas en Chile, estarán facultadas para adquirir, poseer, ceder y administrar, ciñéndose a las reglas del derecho canónico, sus bienes muebles e inmuebles, como también para comparecer ante las autoridades del Estado en resguardo de sus derechos civiles". Es decir, se sujetaba la materia patrimonial de las personas jurídicas religiosas "a la legislación chilena", sin que nada se dijera acerca de la calificación de la personalidad jurídica de las mismas. Las autoridades chilenas trasladaban sin más a la realidad nacional, la regulación contenida en los concordatos celebrados por esos años por la Santa Sede, sin tomar en cuenta la diversidad de las

13 Salinas Araneda, Carlos (2012) "Un primer proyecto de concordato entre Chile y la Santa Sede en 1928”. Revista Chilena de Derecho, vol. 39, No 3, pp. 665-698.

14 Concordato con la República de Polonia (1925), art. I: "La Iglesia Católica, sin distinción de ritos, gozará en la República de Polonia de plena libertad. El Estado garantiza a la Iglesia el libre ejercicio de su poder espiritual y de su jurisdicción eclesiástica, asi como la libre administración y gestión de sus asuntos y de sus bienes, conforme a las Leyes divinas y al derecho canónico". Enchiridion (2003) 654-656.

15 En el original, las palabras "conforme al Derecho Canónico" están subrayadas con línea simple; y las palabras "en cuanto no se oponga a las leyes chilenas" están subrayadas con línea doble. 
realidades de que se hacían eco esos concordatos y, de paso, no tomaba partido en la discusión que ya se había planteado en Chile acerca de la personalidad jurídica de la Iglesia.

\section{(1.4.) El CONTRAPROYECTO DEL NUNCIO}

Cuando el nuncio en Chile recibió el proyecto del gobierno, encontró en él una serie de materias que no eran aceptables en la forma en que estaban reguladas, por lo que presentó un contraproyecto ${ }^{16}$. Según el artículo $1^{\circ}$ de este: "La Iglesia Católica gozará en el territorio de la República de Chile de plena independencia en el ejercicio de su ministerio espiritual, y de todas las libertades necesarias para el cumplimiento de su divina misión". Esta norma se complementaba con la inmediatamente siguiente, según la cual: "El Gobierno de Chile asegura a la Iglesia Católica, en los organismos que de ella dependen según el derecho canónico, el libre ejercicio de su poder espiritual y de su jurisdicción eclesiástica, y le reconoce la personería jurídica de derecho público, que le es propia".

El artículo 2 del proyecto del nuncio, al igual que el mismo artículo de los dos proyectos del gobierno, aseguraba a la Iglesia Católica y a los organismos que de ella dependían el libre ejercicio de su poder espiritual y de su jurisdicción eclesiástica, pero el proyecto del representante papal agregaba un dato nuevo que estaba ausente en los proyectos gubernamentales: la personalidad jurídica de derecho público, la que, con una redacción poco clara, se extendía a la Iglesia "en los organismos que de ella dependen según el derecho canónico".

El tema preocupaba al nuncio porque las consecuencias que traía el que la Iglesia pasara a ser persona jurídica de derecho privado no eran menores conforme a la legislación que entonces estaba vigente. En la carta de 30 de mayo de 1928, con la que el nuncio envió al cardenal Secretario de Estado el proyecto gubernamental que le había entregado el ministro de Relaciones Exteriores y el nuevo proyecto por él redactado ${ }^{17}$, le hacía presente que, al examinar la propuesta del gobierno, había tenido presente, sobre todo, la necesidad de aclarar la situación jurídica de la Iglesia en Chile, puesto que no pocos juristas, fundados en el artículo 10 de la Constitución de 1925, negaban a la Iglesia y a los organismos dependientes de ella la personalidad jurídica de derecho público y apenas le reconocían la de derecho privado. El problema, a la sazón, era que el régimen jurídico de unas y otras era notablemente diferente en lo que se refería a la posesión y administración de bienes inmuebles.

16 Salinas Araneda, Carlos (2014) "El tercer proyecto de concordato entre Chile y la Santa Sede en 1928. Texto y comentario". Revista de Derecho de la Pontificia Universidad Católica de Valparaiso, vol. 42, No 1, pp. 555-595.

17 Carta de 30 de mayo de 1928, en ASV. AES. Cile 1927-1933. Pos. 283-285 P.O. fasc. 47. 
Explicaba el nuncio al cardenal que, mientras las personas jurídicas de derecho público podían adquirir, conservar y administrar bienes muebles e inmuebles, sin ninguna limitación, las personas de derecho privado: i) una vez adquirido un inmueble, no podían conservarlo más allá de cinco años, sin una autorización legal concedida por una de las dos Cámaras; ii) si en el término antedicho no habían conseguido la autorización referida, caían en comiso, y el bien pasaba al fisco; iii) aun cuando hubiesen sido autorizados a conservarlo, no podían venderlo o hipotecarlo sin una especial licencia del tribunal ${ }^{18}$. Todavía más grave se presentaba la situación para las diócesis creadas después de la promulgación de la citada Constitución ${ }^{19}$, ya que, como advertía el nuncio, no faltaban juristas, "incluso católicos", que, partiendo del principio de que las personas de derecho privado no subsistían sino en fuerza de una ley o de un decreto, sostenían que las diócesis antedichas no tenían ninguna personalidad jurídica, pues no existía un decreto o una ley que las reconociesen.

El problema no era un simple ejercicio intelectual, sino que estaba creando problemas en la práctica. En efecto, cuando el nuncio ya había iniciado sus gestiones oficiosas para el concordato, recibió una carta del obispo de Chillán, Martín Rucker Sotomayor, de fecha 28 de marzo de $1928^{20}$, quien le ponía en su conocimiento que, con motivo de un prestamo que había solicitado por $\$ 20.000$, ofreciendo en garantía la hipoteca de una propiedad situada en la misma ciudad, propiedad que había adquirido el 20 de septiembre de 1926, esto es, después de la entrada en vigencia de la nueva Constitución, había recibido respuesta negativa a su

18 Código Civil, art. 556: "[inc. 1] Las corporaciones pueden adquirir bienes de todas clases a cualquier título, pero no pueden conservar la posesión de los bienes raíces que adquieran, sin permiso especial de la legislatura. [inc. 20] Sin este permiso especial, estarán obligadas a enajenar dichos bienes raices, dentro de los cinco años subsiguientes al dia en que hayan adquirido la posesión de ellos; y si no lo hicieren, caerán en comiso los referidos bienes. [inc. 30] Esta prohibición no se extiende a los derechos de censo o pensión, asegurados sobre bienes raices; ni a los derechos de usufructo, uso o habitación". Código Civil, art. 557: "Los bienes raices que las corporaciones posean con permiso especial de la legislatura, están sujetos a las reglas siguientes: $1^{\circ}$ No pueden enajenarse, ni grabarse con hipoteca, censo, usufructo o servidumbre, ni arrendarse por más de ocho años, si fueren predios rústicos, ni por más de cinco, si fueren urbanos, sin previo decreto de juez, con conocimiento de causa, y por razón de necesidad o utilidad manifiesta. 2o Enajenados, puede adquirirlos otra vez la corporación, y conservarlos sin especial permiso, si vuelven a ella por la resolución de la enajenación y no por un nuevo titulo; por ejemplo, cuando el que los ha adquirido con ciertas obligaciones, deja de cumplirlas, y es obligado a la restitución, o cuando ella los ha vendido, reservándose el derecho de volver a comprarlos dentro de cierto tiempo, y ejercita este derecho".

19 El mismo día de la entrada en vigencia de la nueva Constitución, el 18 de octubre de 1925, Pío XI erigió los obispados de San Felipe, Valparaíso, Rancagua, Talca, Linares, Chillán y Temuco; y el 14 de diciembre siguiente designó sus obispos residenciales. ASV. AES., Nunziatura Apost. di Cile, Archivio di mons. Ettore Felici, nuncio apostólico, pos. $1^{\mathrm{a}}$ 
petición mientras no cumplieran los artículos 556 y 557 del Código Civil y obtuviera las autorizaciones que se contemplaban en los mismos ${ }^{21}$.

El mismo nuncio reconocía que, afortunadamente, no todos pensaban de tal modo, por lo que no le parecía difícil demostrar que, "según la letra de la Constitución”, la Iglesia continuaba gozando en Chile de la personalidad jurídica de derecho público, que le había sido reconocida "desde el tiempo de la colonización española”. Con todo, no excluía que la intención de los redactores del artículo 10 de la Constitución hubiese sido "precisamente la de disminuir los derechos de la Iglesia", por lo que consideraba "urgente" definir de una vez para siempre "la grave cuestión”, aprovechando el concordato, el cual, aceptado por el gobierno y ratificado por las dos Cámaras, asumiría el valor de una interpretación auténtica de la Constitución y cortaría toda la discusión.

Consecuente con lo anterior, el nuncio agregaba en su contraproyecto un nuevo artículo, con el número 3, según el cual: "Todas las personas jurídicas eclesiásticas y religiosas, reconocidas como tales por el Derecho Canónico, gozarán, por consiguiente, de plena libertad para adquirir, a titulo oneroso o gratuito, toda clase de bienes, muebles o inmuebles, para poseerlos, administrarlos, gravarlos o enajenarlos, conforme al Derecho Canónico y a las leyes actualmente en vigor para las personas jurídicas de derecho público, como también para comparecer ante las autoridades del Estado en resguardo de sus derechos civiles".

Se trataba de un artículo nuevo que el nuncio redactaba recogiendo, por un lado, aquella parte del artículo 2 de los dos proyectos gubernamentales en los que se aseguraba a la Iglesia y a los organismos que dependían de ella, la libre administración de sus bienes y negocios conforme al derecho canónico y a las leyes chilenas; y, por otra, los artículos de dichos proyectos, según los cuales las iglesias, los ordinarios, las parroquias y las comunidades religiosas legalmente establecidas en Chile estaban facultadas para adquirir, poseer, ceder y administrar bienes ciñéndose al derecho canónico y conforme a la legislación chilena. El proyecto del nuncio le daba autonomía a esta libertad, la que conectaba con la personalidad jurídica de derecho público, interesado como estaba de que quedara firmemente asentada. Esta "plena libertad" era una consecuencia - "por consiguiente" - de dicha personalidad jurídica de derecho público, y disfrutaban de ella "todas las personas eclesiásticas y religiosas reconoci-

21 Ejemplos de autorizaciones concedidas conforme al artículo 556 del Código Civil se pueden ver en Diario Oficial de 20 octubre 1926, respecto de la corporación denominada Iglesia Alianza Cristiana; Diario Oficial de 11 julio 1927, respecto de la corporación denominada Sociedad Evangélica Bautista; Diario Oficial de 1 agosto 1927 y de 20 diciembre 1927, respecto de la institución denominada Instituto de Caridad Evangélica o Hermandad de Dolores; Diario Oficial de 3 febrero 1928, respecto de la corporación denominada Iglesia de los Adventistas del Séptimo Día; Diario Oficial de 17 septiembre 1928, respecto de la institución denominada Iglesia Evangélica Alemana del Lago Llanquihue; etc. 
das como tales por el derecho canónico", esto es, las que el Código Civil denominaba “iglesias" y "comunidades religiosas". El texto del artículo las dejaba bien resguardadas y quedaban superadas las dudas del diplomático vaticano.

\section{2) LAS NUEVAS PREOCUPACIONES DEL NUNCIO}

Un año después de dicha carta, el 17 de abril de 1929, cuando la conversaciones entre el nuncio y el gobierno acerca del concordato se habían estancado y había entrado en escena el arzobispo de Santiago, don Crescente Errázuriz ${ }^{22}$, el nuncio volvía a abordar en un despacho al cardenal secretario de Estado, ahora in extenso, del tema de la personalidad jurídica de la Iglesia ${ }^{23}$. La razón de su preocupación estaba en que el vicario general del arzobispado le había comunicado pocos días antes, que el embajador de Chile ante la Santa Sede habría enviado al gobierno un cablegrama según el cual el cardenal secretario de Estado se habría declarado dispuesto a no insistir en la personalidad jurídica de derecho público y habría aceptado insertar en el concordato el discutido artículo 10 de la Constitución de $1925^{24}$. El sorprendido nuncio estaba dispuesto, como siempre, a atenerse escrupulosamente a las instrucciones del cardenal, pero consideraba su deber reclamar su atención con una serie de observaciones.

La primera de ellas era una breve y evidente afirmación: la Constitución de 1925 reconocía la personalidad jurídica de la Iglesia en cuanto la declaraba "sujeto de derechos determinados" como eran los de erigir y de conservar templos, etc. Más extensa era la segunda afirmación, en la que el nuncio entendía que la misma Constitución le reconocía a la Iglesia, por lo que miraba a los bienes, la personalidad jurídica de derecho público, toda vez que, al decir el artículo 10 que "las iglesias, las confesiones $e$ instituciones religiosas de cualquier culto, tendrán los derechos que otorgan

22 Salinas Araneda, Carlos (2014) "Crónica de la tramitación de un proyecto de concordato entre Chile y la Santa Sede en 1928”. Revista de Estudios Histórico-Jurídicos, vol. 36, pp. 483-512.

23 Carta de 17 de abril de 1929, en ASV. AES. Cile IV-Per 1927-1933. Pos. 283-285 P.O. fasc. 47.

24 Constitución de 1925, art. 10: "La Constitución asegura a todos los habitantes de la República: $2^{\circ}$ [inc. $1^{\circ}$ ] La manifestación de todas las creencias, la libertad de conciencia y el ejercicio libre de todos los cultos que no se opongan a la moral, a las buenas costumbres o al orden público, pudiendo, por tanto, las respectivas confesiones religiosas erigir y conservar templos y sus dependencias con las condiciones de seguridad e higiene fijadas por las leyes y ordenanzas. [inc. 20] Las iglesias, las confesiones e instituciones religiosas de cualquier culto, tendrán los derechos que otorgan y reconocen con respecto a los bienes, las leyes actualmente en vigor; pero quedarán sometidas, dentro de las garantías de esta Constitución, al derecho común para el ejercicio del dominio de sus bienes futuros. [inc. $3^{\circ}$ ] Los templos y sus dependencias, destinados al servicio de un culto, estarán exentos de contribuciones". 
y reconocen con respecto a los bienes, las leyes actualmente en vigor", las leyes en vigor a la época de la promulgación reconocían explícitamente a la Iglesia el carácter de persona jurídica de derecho público, en concreto, el artículo 547 del Código Civil que nunca había sido abrogado ${ }^{25}$. Era claro, en consecuencia, que la Iglesia no había perdido, en fuerza de la Constitución, su personalidad jurídica y gozaba, por lo que se refería a los bienes poseídos anteriormente, de las prerrogativas de una persona jurídica de derecho público. Esta tesis, que al nuncio le parecía irrebatible, era sostenida por juristas de valor y defendida "luminosamente" por Luis Claro Solar en la "obra magistral", Explicaciones de derecho civil chileno y comparado ${ }^{26}$.

La tercera observación, extensa como la anterior, decía relación con la única modificación que, en opinión del nuncio, aportaba la Constitución a la situación jurídica de la Iglesia al referirse al "ejercicio del dominio de sus bienes futuros" en el paso constitucional según el cual "pero quedarán sometidas, dentro de las garantias de esta Constitución, al derecho común para el ejercicio del dominio de sus bienes futuros", paso que había dado lugar a las discusiones. Ante todo, se preguntaba el nuncio, ¿qué se entiende por "ejercicio del dominio"? Algunos pensaban que la frase comprendía todo lo que sigue a la adquisición del dominio; otros entendían que esa expresión designaba el conjunto de actos jurídicos que se referían al uso de los bienes y que no modificaban la propiedad, como el arriendo, la hipoteca, etc. Esta segunda interpretación dejaba a la Iglesia completamente libre en lo referido a la adquisición y a la conservación de sus bienes. La primera, en cambio, restringía su libertad al derecho de adquirir y la sometía en lo demás, al derecho común.

No menos diversas eran las opiniones acerca del valor que debía atribuirse a la fórmula "derecho común". Juristas eminentes opinaban que podía tratarse de un derecho hipotético, aun no formado, al cual deberían someterse todas las iglesias y confesiones ${ }^{27}$. No pocos abogados sostenían que por derecho común debía entenderse la legislación en vigor para las personas naturales. Otros, finalmente, afirmaban que bajo las dos pala-

25 Código Civil, art. 547 inc. 20: "Tampoco se extienden las disposiciones de este título a las corporaciones ofundaciones de derecho público, como [...] las iglesias, las comunidades religiosas [...]: estas corporaciones y fundaciones se rigen por leyes y reglamentos especiales".

26 Claro Solar, Luis (1927) Explicaciones de derecho civil chileno y comparado, V: De las personas. Santiago: Imprenta Cervantes, 611 pp., pp. 455-458. Las páginas de la obra de Claro Solar recién citadas se encuentran transcritas con máquina de escribir y agregadas a los papeles del nuncio. ASV. AES., Nunziatura Apost. di Cile, Archivio di mons. Ettore Felici, nuncio apostolico, pos. $4^{\mathrm{a}}$.

27 He aquí un atisbo, inconsciente por cierto, de lo que con el tiempo se conocería como derecho eclesiástico del Estado. Pensemos que por estos años, la libertad religiosa, si bien reconocida en algunos textos como la Declaración de Derechos de Virginia (1776) y en la Declaración de los Derechos del Hombre y del Ciudadano de la Revolución Francesa (1789), todavía no era un derecho universalmente reconocido. 
bras de color oscuro se escondían las disposiciones legales que regían a las personas jurídicas de derecho privado contenidas en el título XXXIII del libro I del Código Civil. La Constitución, según estos últimos, habría modificado implícitamente el artículo 547 del Código Civil que declaraba que no se extendían a las personas jurídicas de derecho público, como las iglesias, las comunidades religiosas y otras, las disposiciones del referido título XXXIII. Claro Solar, hacía presente el nuncio al secretario de Estado, se declaraba a favor de esta última opinión, si bien confesaba "cándidamente" que la carta fundamental no se distinguía en este punto, por su excesiva claridad.

En una cuarta observación, el nuncio entendía que, cualquiera que fuere el valor que se atribuyera a las dos fórmulas, era cierto, en su opinión, que la Constitución: i) confirmaba la personalidad jurídica de la Iglesia; ii) le reconocía el carácter de persona jurídica de derecho público, limitando únicamente el ejercicio del dominio respecto de los bienes adquiridos después de 1925. En otras palabras, la Iglesia, según la Constitución, era "persona de derecho público, sometida parcialmente a las restricciones establecidas por el Código para las personas de derecho privado" 28 .

Era por lo que la objeción de los radicales, según la cual el reconocimiento de dicha personalidad a favor de la Iglesia Católica implicaría el mismo privilegio a favor de las otras confesiones, estaba privada de fundamento. En efecto, la Constitución no había creado, sino simplemente reconocido la personalidad de las iglesias, confesiones e instituciones religiosas, confirmando el derecho de que gozaban anteriormente. Ahora bien, solo la Iglesia Católica, antes de 1925, tenía el carácter de persona de derecho público; las otras confesiones no tenían existencia jurídica, a menos que hubiesen sido constituidas como corporaciones, con las normas y con las características específicas de las personas de derecho privado. Era, por lo tanto, "ridículo" pretender, en nombre de la Constitución, poner al mismo nivel a la Iglesia Católica y las otras confesiones.

La extensa carta del representante pontificio continuaba con una quinta observación: la situación constitucional creada a la Iglesia era "una monstruosidad jurídica", portadora de la mentalidad sectaria que la imaginó, con la intención, afortunadamente frustrada por la oposición Católica, de reducir a la Iglesia al nivel de cualquier corporación. La redacción del artículo 10 de la Constitución mostraba por sí mismo la lucha trabada, al tiempo de la constituyente, entre el partido conservador y el elemento radical dominante; y el tan discutido inciso, referido al ejercicio del dominio de los bienes futuros, no era sino que "el fruto, infeliz,

\footnotetext{
28 "In altri termini, la Chiesa, secondo la Costituzione, é persona di diritto pubblico, sommessa parcialmente alle restrizioni stabilite dal Codice per le persone di diritto privato". ASV. AES. Cile 927-1933. Pos. 283-285 P.O. fasc. 47.
} 
de una deplorable transacción, en la cual cada una de las dos partes salió de la pista, convencida de haber ganado la partida. Los conservadores creyeron haber salvado la personalidad de derecho público de la Iglesia, confirmando los derechos que esta gozaba; los radicales pensaron de haberla liquidado, sometiéndola, en el futuro, a algunas restricciones propias de las personas de derecho privado" 29.

Agregaba el nuncio que lo extraño de la situación no justificaba el razonamiento "pueril" de los radicales, quienes, de la limitación establecida al ejercicio del dominio de los bienes futuros sacaban la consecuencia de que la Iglesia había perdido su naturaleza de persona jurídica de derecho público. "Para llegar a semejante conclusión sería necesario engullir dos absurdos igualmente indigestos incluso para un estómago radical: o que el segundo inciso del citado artículo 10 destruye al primero, que reafirma los derechos y las prerrogativas anteriores de la Iglesia; o que una persona juridica puede ser, al mismo tiempo, de derecho público y de derecho privado" 30.

La sexta observación la empezaba recapitulando que la Constitución no había modificado la naturaleza de la personalidad de la Iglesia, que había venido a ser confirmada en su carácter de persona jurídica de derecho público. Era por lo que la única discusión posible versaba sobre el valor del inciso que ponía restricciones al ejercicio del dominio, restricciones que, en la peor de las interpretaciones, podrían ser aquellas previstas por el Código Civil para las personas jurídicas de derecho privado. Conforme a esto, aclarar dicho inciso, dándole un significado conforme a la naturaleza y a la dignidad de la Iglesia, debía ser, en opinión del diplomático pontificio, la tarea principal de un concordato, el que no le parecía difícil si había un poco de buena voluntad de parte del gobierno.

Sugería el nuncio adoptar la segunda de las interpretaciones por él indicadas, entendiendo por "derecho común" el derecho en vigor para todos los ciudadanos de la República. Los radicales objetaban que, en tal caso, la Iglesia quedaba en la misma situación tanto respecto de sus bienes pasados como futuros, en atención a que el Código no establecía ninguna restricción para las personas naturales, por lo que el segundo paso del inciso segundo del artículo 10 no sería más que una inútil repetición del

29 "Il tanto discusso inciso, riguardante l'esercizio del dominio deu beni futuri, non é che il fruto, infelice, de una deplorevole transazione, nella quale cisacuna delle due parti usci dalla pista, convinta di aver guadagnato la partita. I conservatori credettero di aver salvato la personalitá di diritto pubblico della Chiesa, confermando i diritti di cui questa godeva; $i$ radicali pensarono di averla liquidata, sommettendola, per l'avvenire, ad alcune restrizioni proprie delle persone di diritto privato". ASV. AES. Cile 1927-1933. Pos. 283-285 P.O. fasc. 47.

30 "Per giungere a siffatta conclusione sarebbe necesario trangugiare due assurdi igualmente indigesti, anche per uno stomaco radicale: o che il secondo inciso del citato articolo 10 distrugge il primo, che riafferma $i$ diritti e le prerogative anteriori della Chiesa; o che una persona giuridica puó essere, allo stesso tempo, "di diritto pubblico» e "di diritto privato»". ASV. AES. Cile 19271933. Pos. 283-285 P.O. fasc. 47. 
primero. Pero el "engañoso" argumento estaba privado de valor. La diferencia querida existiría también en la interpretación indicada, y estaría suficientemente justificado el "pero" que dividía los dos pasos del inciso, en cuanto a que la situación de la Iglesia, por lo que mira a sus bienes pasados, sería de carácter constitucional y, por lo mismo, inmutable mientras no se cambiare la carta fundamental; en cambio, para los bienes futuros, sería por el momento, la misma, pero quedaría expuesta a la posible modificación del Código Civil.

Convenía el diplomático que, de la historia de la Constitución y del examen de las actas resultaba clara la intención de los radicales de reducir la Iglesia a la condición de persona jurídica de derecho privado. Pero no comprendía que el gobierno con el que tenía que actuar, deseoso de mantener relaciones con la Iglesia, tuviera que atenerse a la historia, cuando la letra de la Constitución se prestaba evidentemente a una benévola y más razonable interpretación.

Finalmente, en el apartado séptimo de su extenso informe, el nuncio entendía que limitarse a afirmar en un concordato la sola "personalidad jurídica" de la Iglesia, sin entrar a calificarla, sería invocar como concesión un derecho que daba la Constitución. Prescindir en la sustancia y en la forma de la personalidad jurídica de derecho público, significaría renunciar voluntariamente a una situación de favor que reconocía la propia Constitución y poner a la Iglesia al nivel de una corporación de derecho privado, las cuales, sin hablar de la restricción relativa al ejercicio del dominio, dependían, en su misma existencia, de un decreto del ministro del Interior o de una ley del Estado. El prelado hablaba de sustancia y de forma porque no veía dificultad en que se renunciase a la fórmula "persona jurídica de derecho público" siempre y cuando se asegurase a la Iglesia, de hecho, el tratamiento correspondiente.

En lo que se refería a insertar en el concordato el discutido artículo 10, lo encontraba peligroso, a menos que se afirmara claramente que, no obstante la limitación que ella aportaba al ejercicio del dominio, la Iglesia quedaba, para todos los otros efectos, persona jurídica de derecho público. Era peligrosa por el abuso que ilógicamente harían de ella los radicales. Pero, además, era inoportuna, por cuanto dejaba las cosas en la penosa situación del momento, o, peor aun, consagraría, dado el sentido que se le quería atribuir, la peor de las interpretaciones que se le daba al inciso antedicho.

El hecho que había originado el extenso despacho del nuncio era, como lo señalé, que el vicario general del arzobispado le había comunicado pocos días antes, que el embajador de Chile ante la Santa Sede habría enviado al gobierno un cablegrama según el cual el cardenal secretario de Estado se habría declarado dispuesto a no insistir en la personalidad jurídica de derecho público y habría aceptado insertar en el concordato el 
discutido artículo 10 de la Constitución de 1925. El despacho del nuncio estaba fechado en Santiago, el 17 de abril de 1929; pero el diplomático no quedó tranquilo, por lo que pocos días después, el 25 de abril de 1929, envió al secretario de Estado un telegrama en el que, en pocas palabras, le decía que la embajada de Chile ante la Santa Sede había comunicado al gobierno que el cardenal secretario de Estado estaba dispuesto de buena gana a no insistir en la personalidad jurídica de derecho público y a insertar en el concordato el discutido artículo 10 de la Constitución, por lo que solicitaba se le confirmase la noticia ${ }^{31}$. Que la preocupación del nuncio tuvo eco el Roma lo prueba el hecho que el 10 de mayo de 1929, el embajador de Chile ante la Santa Sede le hizo llegar al cardenal secretario de Estado una breve carta que tan solo transcribía el artículo 10 no 2 de la Constitución. Al día siguiente, 11 de mayo, de su puño y letra, el cardenal respondía al nuncio con otro telegrama en el que, en una sola frase, le decía que no había dicho que estaba dispuesto a no insistir en la personalidad jurídica de derecho público de la Iglesia ${ }^{32}$.

La respuesta formal del secretario de Estado al extenso despacho de abril, vino desde Roma el 13 de junio. En ella el cardenal, además de acusar recibo de dicha misiva en la cual le había expuesto "diversas consideraciones sobre algunos puntos del proyecto de concordato en estudio", le confirmaba lo que el mismo secretario de Estado le había comunicado al nuncio en un cifrado anterior y le agradecía sus gestiones.

\section{3) OTRAS OPINIONES SOBRE LA PERSONALIDAD JURÍDICA DE LA IGLESIA}

Como el tema no era menor, el nuncio fue pidiendo y recibiendo diversas opiniones y pareceres acerca de la situación en que se encontraba la personalidad jurídica de la Iglesia después de la entrada en vigencia de la nueva Constitución de 1925. Algunos de estos pareceres fueron solicitados por él a algunos juristas específicamente sobre el tema que le apremiaba; otros informes, no pedidos por él, se los hicieron llegar, como un informe, quizá el de mayor calidad, que abordó el tema específico de la personalidad jurídica del arzobispado de Santiago, que se encuentra entre los papeles del nuncio, al parecer solicitado por el arzobispado y que le fue entregado. Otros, especialmente de algunos eclesiásticos, abordaban en general el tema del concordato que se estaba gestionando, pero hacían

\footnotetext{
31 "Cotesta Ambasciata comunica Governo che V.E.R. volontieri disposta non insistere personalità giuridica diritto pubblico, e inserire concordato discusso inciso articolo $10^{\circ}$ Costituzione. Prego conformarmi notizia. Segue rapporto. Felici". ASV. AES. Cile 1928-1931. Pos. 283-285 P.O. fasc. 48.

32 "Ricevuto cifrato no 14 . Non ho detto che sono disposto non insistere personalità giuridica diritto pubblico. Card. Gasparri”. ASV. AES. Cile 1928-1931. Pos. 283-285 P.O. fasc. 48.
} 
reflexiones sobre la personalidad jurídica de la Iglesia por la importancia central que tenía.

\section{(3.1.) JURISTAS}

\section{(3.1.1.) Arturo Alessandri Rodríguez, decano de la Facultad de Derecho de la Universidad de Chile: personalidad jurídica de derecho público antes y después de la Constitución de 1925, pero sometida al derecho común respecto de los bienes adquiridos después de la misma}

En medio de este acopio de informes, expresión de que el tema no era indiferente, se encuentra entre los documentos del nuncio Felici un informe emitido por Arturo Alessandri Rodríguez, fechado el 17 de junio de $1931^{33}$, en el que responde a una pregunta que sirve de título al mismo: "EEl arzobispado de Santiago es actualmente persona jurídica de derecho público?”.

Partiendo del hecho indiscutido de que el arzobispado de Santiago era persona jurídica de derecho público al dictarse la Constitución de 1925, la duda se reducía a determinar si ese carácter lo había conservado o lo había perdido para convertirse en una simple persona jurídica de derecho privado. En concepto de Alessandri, se trataba de un problema de retroactividad de la ley, pues se reducía a determinar cuál era el efecto que en esa personalidad jurídica había producido el cambio de legislación. Conforme a ello, la duda debía resolverse con arreglo a los principios que regían en Chile los conflictos que resultaren de la aplicación de las leyes dictadas en épocas diversas.

Dos de los preceptos de la ley sobre efecto retroactivo de las leyes se referían al tema: el artículo 10, según el cual la existencia y los derechos de las personas jurídicas se sujetarían a las mismas reglas referidas al estado civil, haciendo una remisión al artículo 3 de dicha ley, que dispone en su inciso $1^{\circ}$ que "el estado civil adquirido conforme a la ley vigente a la fecha de su constitución, subsistirá aunque esta pierda su fuerza; pero los derechos y obligaciones anexos a él se subordinarán a la ley posterior, sea que esta constituya nuevos derechos u obligaciones, sea que modifique o derogue los antiguos". A la luz de ambos preceptos, parecía claro que, en materia de personalidad jurídica, había que distinguir la existencia de la persona jurídica y las aptitudes, facultades o derechos que de dicha personalidad se desprendían.

33 ASV. AES., Nunziatura Apost. di Cile, Archivio di mons. Ettore Felici, nuncio apostolico, pos. $3^{\text {a }}$. 
Íntimamente relacionada con la existencia de la persona jurídica estaba su calidad de persona jurídica de derecho público o de derecho privado, comoquiera que este carácter dependía de la naturaleza de la regla jurídica a que debía su existencia y de la finalidad para la cual había sido creada. Para el informante, la fisonomía pública o privada de una persona jurídica se determinaba al momento de su creación y era inseparable de su existencia porque precisamente existía y había sido creada para realizar fines de derecho público o de derecho privado. De esto Alessandri deducía dos consecuencias: i) que la calidad de derecho público o privado de una persona jurídica subsistía mientras existiera; ii) esa calidad la conservaba aunque más tarde perdiere su fuerza la ley con arreglo a la cual se constituyó, a menos que la ley posterior se la modificare expresamente. Pero si el legislador guardaba silencio al respecto y se limitaba solamente a alterar la capacidad o las facultades de la persona jurídica, su calidad de persona de derecho público o de derecho privado no se modificaba y continuaba subsistente, a virtud del artículo 10 de la ley sobre efecto retroactivo de las leyes.

Esto era, precisamente, lo que había sucedido con el arzobispado de Santiago, que era persona jurídica de derecho público según la Constitución de 1833. La Constitución de 1925 había cambiado sustancialmente la situación existente al afirmar la libertad de cultos, pero nada había dicho acerca de la personalidad jurídica de estas personas, limitándose solo a reglar la situación de sus bienes: conservaba el statu quo respecto de los bienes ya adquiridos y cambiaba el régimen para los que se adquirieren en el futuro. Cabía, pues, aplicar el artículo 10 de la ley sobre efecto retroactivo de las leyes del cual aparecía claro que la personalidad jurídica subsistía y continuaba existiendo como tal aunque las leyes con arreglo a las cuales se había constituido hubiesen perdido su fuerza. Así, las iglesias e instituciones religiosas que eran personas jurídicas de derecho público al promulgarse la Constitución de 1925 habían continuado siéndolo y los bienes que entonces les pertenecían continuaban sometidos a las leyes en virtud de los cuales habían sido adquiridos.

En cambio, respecto de la futura adquisición de bienes, tenían la capacidad de las personas jurídicas de derecho privado y les eran aplicables las restricciones de los artículos 556 y 557 del Código Civil, con lo que la nueva Constitución había derogado tácitamente el artículo 547 del Código Civil en cuanto mencionaba a las iglesias y comunidades religiosas, pero solo por lo que hacía a sus bienes futuros.

La conclusión de Alessandri era clara: i) el arzobispado de Santiago continuaba siendo persona jurídica de derecho público; ii) en cuanto a los bienes que le pertenecían al promulgarse la nueva Constitución, continuaba gozando de los derechos que, como tal persona, le otorgaban y reconocían las leyes que estaban entonces en vigor; iii) en cuanto al ejerci- 
cio del dominio de sus bienes futuros, aun cuando seguía siendo persona jurídica de derecho público, estaba asimilado a las personas jurídicas de derecho privado y tenía a sus respectos los derechos y las restricciones que para tales personas señalan los artículos 556 y 557 del Código Civil.

\section{(3.1.2.) Otra opinión en la línea de Alessandri: personalidad jurídica de derecho público antes y después de la Constitución de 1925, pero sometida al derecho común respecto de los bienes adquiridos después de la misma}

Se encuentra también un informe sin fecha, que si bien sigue una línea argumentativa diversa del informe de Arturo Alessandri, coincide con él en las afirmaciones finales. Aunque está firmado, no me ha sido posible identificar al autor ${ }^{34}$. El informante se formula tres preguntas a las que pretende dar respuesta en su informe: i) ¡conserva personalidad jurídica la Iglesia y sus organismos después de promulgada la Constitución del año 1925?; ii) ¿qué clase de personalidad jurídica es esta?, iii) ¿rige para con ella el título XXXIII del libro I del Código Civil relativo a las personas jurídicas?

Al reconocer la Constitución que las confesiones religiosas pudieren erigir y conservar templos, presuponía necesariamente la existencia de una entidad jurídica a quien se reconocía una garantía constitucional, capaz de ser amparada y apta para adquirir y poseer templos y dependencias y, por ende, de adquirir y poseer los medios económicos indispensables para poder erigir y poseer los referidos bienes. "Por consiguiente, a la luz de esta disposición constitucional, surge con luz meridiana la capacidad de la Iglesia y su reconocimiento en cuanto persona juridica". Quedaba respondida la primera pregunta.

Como la Constitución no había innovado respecto de la personalidad jurídica de la Iglesia Católica, había que definir qué tipo de personería jurídica tenía después de 1925 . Si la nueva Constitución no había innovado, había que concluir que continuaba teniendo personalidad jurídica de derecho público, y solo tuvo que pronunciarse respecto de la personalidad jurídica de las otras confesiones religiosas, toda vez que la Constitución de 1833 nada había dicho respecto de ellas, pues la religión Católica era la oficial del Estado. "Por consiguiente, la parte segunda del inciso $1^{\circ}$ del $n^{\circ} 2$ del artículo 10 de la nueva Constitución, no tiene otro alcance que reconocer la personalidad juridica de las confesiones religiosas que no son la Iglesia Católica, sin modificar ni innovar con respecto a esta última que era la única existente antes de la nueva Constitución". Así, las

\footnotetext{
34 ASV. AES., Nunziatura Apost. di Cile, Archivio di mons. Ettore Felici, nuncio apostolico, pos. $4^{\mathrm{a}}$.
} 
otras confesiones religiosas podrían constituirse como personas jurídicas conforme al título XXXIII del libro I del Código Civil. Quedaba así respondida la segunda pregunta.

En relación con los bienes que la Iglesia, persona jurídica de derecho público, tenía al año 1925, conservaba plena capacidad sin limitación alguna. Pero ¿qué significado tenía para la Iglesia el que la Constitución estableciera que las confesiones religiosas quedaban sometidas al derecho común para el ejercicio del dominio de sus bienes futuros? "Con relación a los bienes adquiridos con posterioridad a su vigencia, conserva su plena capacidad de goce, quedando sometida su capacidad de ejercicio a las trabas impuestas a las personas jurídicas regidas por el título 33 del Código Civil'. Ello era así, para todas las entidades eclesiales existentes a 1925. Respecto de los nuevos obispados creados por la Santa Sede y las nuevas parroquias erigidas por los Ordinarios, "creo indiscutible que si bien es cierto que gozan de personalidad jurídica de derecho público con arreglo a la nueva Constitución Politica, no es menos cierto que esta personalidad jurídica solo les da la capacidad de goce, quedando su capacidad de ejercicio sometida a todas las trabas de las personas regidas por el título 33 del Código Civil. Y esto por una razón muy sencilla: la nueva Constitución excluye, como hemos visto anteriormente, de las prescripciones del título indicado del Código Civil, con respecto a la capacidad de ejercicio, solo a los bienes adquiridos con anterioridad a la vigencia de la nueva Constitución y como, tratándose de los nuevos obispados o nuevos organismos de la Iglesia, no cabe aplicar a estos tal principio por cuanto mal podian poseer bienes si no existian, hay que llegar a fortiori a la conclusión de que los bienes de estos nuevos organismos no caen en la excepción que consigna la Constitución respecto de los bienes existentes". Como puede advertirse, lo anterior, que no difiere de lo planteado por Alessandri, pero aborda un aspecto no tratado por Alessandri: la situación patrimonial de las personas jurídicas creadas con posterioridad a la Constitución de 1925 .

\section{(3.1.3.) Romualdo Silva: persona jurídica de derecho constitucional con características de la personalidad de derecho público}

Había sido profesor de derecho civil y de derecho procesal, diputado, senador y miembro de la comisión de reforma constitucional, habiendo acompañado al nuncio de la época, Benedetto Aloisi Masella y, como él mismo lo reconoce, había hablado "constantemente", con el Presidente Alessandri y con sus colegas de la comisión "sobre la cuestión religiosa". El 10 de enero de 1932, a petición del nuncio Felici, emitió un informe "en orden a la situación de la Iglesia Católica y de algunas instituciones 
religiosas" 35 . Según el informante, las leyes vigentes en 1925 otorgaban y reconocían la personalidad jurídica de derecho público de la Iglesia Católica y de sus instituciones principales. La nueva Constitución había dispuesto que se continuara porque los derechos sobre bienes que constituían esa personalidad, formaban el régimen constitucional y legal que estaba en vigor. "Solamente para el ejercicio del dominio de bienes futuros se declaró el sometimiento al derecho común, dentro de la inviolabilidad y otras garantias de la propiedad privada que establece la misma Constitución Politica".

Para los efectos de la personalidad de la Iglesia e instituciones religiosas que tenían en 1925 derechos que les otorgaba la Constitución de 1833 y las leyes en vigor, la nueva Constitución había incorporado al nuevo régimen constitucional ese sistema de reconocimiento y otorgamiento de derechos. "En consecuencia, hay una personalidad juridica, que por lo menos puede llamarse de derecho constitucional reconocida a la Iglesia Católica y sus instituciones, personalidad que no es de derecho privado, que no podría ser alterada por simples leyes futuras y que tiene todas las características de la personalidad de derecho público".

Es por lo que "para acentuar, ratificar o vigorizar ese concepto", la misma Constitución de 1925 había establecido la excepción o limitación relativa al simple ejercicio, no a la adquisición ni a la conservación, del dominio de bienes futuros, sometiendo esto al derecho común, "o sea a las leyes actualmente vigentes y a las que se dicten sobre la propiedad privada de personas naturales o jurídicas". Así, bajo la nueva Constitución, las iglesias, comunidades e instituciones de la religión Católica que existían en 1925, al reformarse la Constitución de 1833 "fueron las favorecidas por la reforma que estableció el régimen de separación, con la conservación de sus personalidades juridicas para bienes y derechos. El tenor literal y la historia fidedigna de la reforma constitucional autorizan la interpretación expresada".

El ex parlamentario agregaba un nuevo argumento, más político que jurídico: "los católicos no podiamos aceptar jamás la separación. Ante la imposibilidad moral y material de evitar que otros, en mayoria, la hicieran en Chile, hicimos las protestas y reservas doctrinarias y expresamos los votos en contra que constan de las actas oficiales; $y$, no pudiendo impedirla, dejamos pasar la separación de la Iglesia del Estado; pero para dejarla pasar con nuestra concurrencia a los labores de reforma de la Constitución fue más que necesario, fue esencial, conseguir algunas cosas importantes. Una de esas cosas, fue la disposición de la cual se deriva esa personalidad de derecho constitucional expresada en la forma del artículo diez numero dos".

35 ASV. AES., Nunziatura Apost. di Cile, Archivio di mons. Ettore Felici, nuncio apostolico, pos. $4^{\mathrm{a}}$. 
En suma, las iglesias, comunidades e instituciones de la religión Católica que existían en 1925, al reformarse la Constitución de 1833, fueron las favorecidas por la reforma que estableció el régimen de separación, con la conservación de sus personalidades jurídicas para bienes y derechos. Pero el informe nada decía respecto de las nuevas entidades creadas después de 1925, como los nuevos obispados o parroquias.

\section{(3.1.4.) Miguel L. Valdés, una opinión disidente: la Iglesia debe organizarse como persona jurídica de derecho privado -corporaciones y fundaciones- a partir de la nueva Constitución}

También sin fecha es el informe de Miguel L. Valdés, que se encuentra en el archivo del nuncio Felici y que, con seguridad, fue evacuado a petición del mismo diplomático ${ }^{36}$. Habrá sido una sorpresa para este, pues se sitúa en una línea del todo diferente a los anteriores. Según Valdés, al haber sido suprimido el artículo 4 (antiguo artículo 5) de la Constitución de 1833, la religión Católica habría dejado de ser una entidad constitutiva del Estado, y los organismos de la Iglesia Católica ya no tendrían la calidad de personas jurídicas de derecho público que, como derivación del precepto constitucional derogado, les reconocía el artículo 547 del Código Civil.

"Abolida la personalidad de derecho público que, según lo dicho, correspondia a la Iglesia Católica, en determinados organismos, para adquirir la personalidad civil de derecho privado, única que ahora podría obtener para todos los efectos que no se refieran a sus bienes, parece indudable que la Iglesia tendrá que someterse a los preceptos contenidos en el título XXXIII del libro $1^{\circ}$ del Código Civil, en lo relativo a la formación y reconocimiento de las corporaciones o fundaciones, según su naturaleza e indole. Asi, habria que organizar las comunidades religiosas como corporaciones de derecho civil, sometiéndose los estatutos a la aprobación del Presidente de la República; y de la misma manera tendrian que erigirse en fundaciones de derecho civil las parroquias, los cementerios, etc.".

La personalidad jurídica la Iglesia la conservaba, sin embargo, en lo que se refería a los bienes, pues la misma Constitución le reconocía a las corporaciones e instituciones religiosas de cualquier culto los derechos que otorgaban y reconocían, con respecto a los bienes, las leyes que estaban en vigor; como se les reconocía la personalidad jurídica solo respecto a los bienes, "en todo lo demás desaparece la personalidad que les reconocian las leyes preexistentes". Reconocida para las instituciones religiosas católicas la

36 ASV. AES., Nunziatura Apost. di Cile, Archivio di mons. Ettore Felici, nuncio apostolico, pos. $4^{\mathrm{a}}$. 
personalidad de derecho público, "sometida según el artículo 547 del Código Civil a las leyes y reglamentos especiales del derecho canónico, esta exención del derecho común solo se refiere a los bienes incorporados al dominio de la Iglesia con anterioridad a la promulgación de la nueva Constitución; los bienes que se adquieran con posterioridad se rigen por el derecho común a todas las personas juridicas de que trata el titulo XXXIII del libro $1^{\circ}$ del Código Civil, entre los [que se encuentran] los articulos 556 y 557 ”.

Miguel Valdés reconocía que las conclusiones a las que había arribado en su informe podían "ofrecer serias dudas" a causa, en gran parte, de la oscuridad del texto constitucional, oscuridad que podía ocasionar en adelante graves dificultades en la solución de problemas tan delicados como los que quedaban insinuados; es por lo que consideraba "como necesaria una declaración legislativa que disipe toda vaguedad e incertidumbre en la aplicación de preceptos de tanta entidad". En suma "no se concibe que haya podido idearse un régimen más odioso y absurdo para la administración de los bienes de la Iglesia".

\section{(3.2.) ECLESIÁSTICOS}

\section{(3.2.1.) Rafael Edwards Salas, obispo auxiliar de Santiago y vicario castrense de Chile: la Iglesia persona de derecho constitucional}

Dos fueron los escritos del obispo Edwards que se encuentran entre los papeles del nuncio: una pro memoria presentada al ministro del Interior y un parecer ante la Sagrada Congregación de Asuntos Eclesiásticos Extraordinarios.

a) pro memoria al ministro del Interior: el 13 de noviembre de 1929 se registró en la Sagrada Congregación para los Asuntos Extraordinarios de la Iglesia una pro memoria presentada por Rafael Edwards Salas, obispo auxiliar de Santiago y vicario castrense de Chile, a Guillermo Edwards, ministro del Interior del Presidente Carlos Ibáñez del Campo ${ }^{37}$. Puesto que el ministro se desempeñó al frente de la cartera del Interior entre el 5 de junio de 1928 y agosto de $1929^{38}$, esta presentación se hizo cuando estaban muy vivas las preocupaciones del nuncio. Es probable que fuera el nuncio quien lo enviara a Roma.

En la parte pertinente de la misma, el obispo decía al ministro que "lo primero que [la Iglesia] necesita es poner al amparo de toda duda y de toda vejación su personalidad y su constitución". Esta debía ser la que es y

ASV. AES. Cile, 1928-1931. Pos. 285 P.O., fasc. 48.

Valencia Avaria, Luis (1986) Anales de la República. 2a edición. Santiago: Editorial Andrés Bello, Tomo I, 736 pp., pp. 576-577. 
no una constitución que resultase una "ficción legal", porque "nadie se hace mejor, ni gana el régimen de las ficciones". Entendía el prelado que la personalidad jurídica de la Iglesia no podía ser la de derecho privado a que se refería el Código Civil. "Basta leer sus artículos para ver que no cabe". Además, agregaba el obispo, "para los bienes pasados, es inamovible su condición de personalidad de derecho público".

Aunque no lo decía, se hacía eco de la posibilidad de que para lo pasado la Iglesia tuviese personalidad jurídica de derecho público y para lo venidero personalidad jurídica de derecho privado, pero, se preguntaba ¿se gana algo consagrando una dualidad monstruosa? Y seguidamente se preguntaba qué significaba que la Iglesia Católica tuviese personalidad de derecho público, respondiendo que "para un constitucionalista, simplemente que esa personalidad está reconocida en el derecho público chileno, es decir, en su Constitución. Esto es un hecho en Chile”. En resumen, en cuanto a nuestro tema, lo que la Iglesia pedía era "el claro reconocimiento de su personalidad para evitarse pleitos y cuestiones y no tener que constituir, a su lado ${ }^{39}$, entidades de derecho privado".

b) parecer ante la Sagrada Congregación de Asuntos Eclesiásticos Extraordinarios: una nueva presentación hizo el obispo Edwards en torno al tema del concordato en la que abordó también el tema de la personalidad jurídica de la Iglesia. Se trata de un texto manuscrito, redactado con su inconfundible caligrafía, estando en Roma, fechado el 12 de noviembre de $1929^{40}$. No tenía un destinatario específico pero, por el título que llevaba el escrito, "Parecer con relación al concordato", con seguridad fue presentado a la Sagrada Congregación para los Asuntos Eclesiásticos Extraordinarios de la Iglesia, donde quedó archivado. Es posible que copia del mismo el obispo le entregara al nuncio a su regreso a Chile.

El texto se abre con una afirmación contundente, del todo aplicable a nuestro tema: "el concordato tiene una indudable y gran ventaja: es el reconocimiento por el Estado de la Iglesia universal como una persona internacional o supra-nacional capaz de derechos". Consideraba el obispo que hacer un buen concordato en el que, juntamente con esa ventaja fundamental, se obtuvieran otras y no se sacrificase nada valioso de la situación que se vivía entonces, sería un gran bien. Pero inmediatamente se preguntaba si, en la práctica, era probable la aprobación del Ejecutivo y la ratificación del Parlamento de un buen concordato, porque era claro para el prelado que "desde luego" se resistiría al reconocimiento de la Iglesia como persona de derecho público. Si se le reconocía solo personalidad jurídica de derecho privado "no hemos ganado nada; perdemos, porque hoy, por la Constitución, la Iglesia es persona podríamos decir de derecho constitucional'.

\footnotetext{
39 En el original, la expresión “a su lado” está subrayada.

40 ASV. AES. Cile, 1928-1931. Pos. 285 P.O., fasc. 48.
} 
Aun cuando Edwards, en su "parecer", aborda diversos tópicos, solo dos puntos tenían "importancia específica” para el concordato: uno de ellos era, precisamente la personalidad jurídica de la Iglesia, el otro, el nombramiento de los obispos. "La Iglesia podría exigir el amplio reconocimiento de su personalidad jurídica de derecho público y que se le exima de la necesidad de pedir autorización para conservar los bienes inmuebles (para los templos y dependencias no se requiere) adquiridos desde septiembre de $1924^{41} y$ de la pretensión de que pida autorización judicial para hipotecar o vender".

En tono realista no exento de cierto pesimismo, el obispo auxiliar opinaba que "la incertidumbre caracteriza nuestro futuro politico. La masoneria influye. El jacobinismo no ha muerto. Una sola cosa aparece clara: se necesitará un milagro para que tengamos un gobierno católico". Y al resumir su texto escribía que el gobierno estaba dispuesto a exigir más de lo que se había dado a Italia, Polonia, Letonia, etc., "y a dar menos de lo que nos es debido, en cuanto a la personalidad de derecho público de la Iglesia". Un buen concordato difícilmente sería aceptado por el gobierno, el que "en ningún caso tendría este la voluntad enérgica, dictatorial para arrancar la aprobación del Parlamento".

\section{(3.2.2.) Gilberto Fuenzalida Guzmán, obispo de Concepción: obtener del gobierno el derecho para el dominio de los bienes adquiridos después de 1925}

Se trata de un parecer hecho a petición de monseñor Giuseppe Pizzardo, secretario de la Sagrada Congregación para los Asuntos Eclesiásticos Extraordinarios, manuscrito por el prelado, en respuesta, probablemente, a un encargo del prelado vaticano que le pedía su opinión "acerca de un proyecto de concordato entre la Santa Sede y la República de Chile" 42. No está fechado, si bien fue registrado en la citada Congregación el 20 de noviembre de 1929, es decir, es contemporáneo a los documentos del obispo Rafael Edwards. Opinaba el prelado penquista que no veía en el gobierno un propósito sincero de hacer un concordato, por lo que entendía que las negociaciones no llegarían a un resultado satisfactorio. En lo referido a la personalidad jurídica de la Iglesia, consideraba que "el reconocimiento de la plena personería juridica de la Iglesia, es decir, del derecho para el dominio de los bienes adquiridos después de 1925 (única restricción que ahora existe), podria obtenerse sin necesidad de un concordato. También podría ejercer libremente el dominio de esos bienes por otros medios legales". Su visión sobre el concordato era negativa, pero no así su visión sobre la

\footnotetext{
41 Hay aquí una errata, porque debió decir septiembre de 1925, mes en el que fue promulgada la nueva Constitución.

42 ASV. AES. Cile, 1928-1931. Pos. 285 P.O., fasc. 48.
} 
realidad de la Iglesia la que, en su opinión, no debía "manifestarse temerosa de su actual situación jurídica". Y en cuanto a su personalidad jurídica, le convendría hacer gestiones eficaces para alcanzar el reconocimiento pleno de su personalidad respecto de todos sus bienes.

A la luz de este "parecer", puede desprenderse que era claro que para el pastor de Concepción: i) la Iglesia conservaba su personalidad jurídica de derecho público; ii) dicha personalidad le permitía actuar como tal persona jurídica de derecho público respecto de todos los bienes adquiridos con anterioridad a 1925; iii) es por lo que la Iglesia no debía "manifestarse temerosa de su actual situación jurídica" iii) solo había que obtener del gobierno el "derecho para el dominio de los bienes adquiridos después de 1925". Pero ¿qué significaba esto?, ¿ya no tenía la Iglesia derecho para adquirir bienes en dominio?, ¿había perdido la Iglesia su personalidad jurídica, como argumentaban algunos, al menos respecto de los bienes adquiridos después de 1925? Las expresiones utilizadas por el prelado no arrojan muchas luces, pero parece claro que el problema de la personalidad jurídica lo excluía para el período anterior a 1925 y lo limitaba solo a la situación creada por la nueva Constitución.

\section{(3.2.3.) Aloisi Masella, nuncio apostólico en Chile entre 1919 y 1927: mientras no se reformare el artículo 547 del Código Civil, la Iglesia continuaría siendo una persona jurídica de derecho público y por consiguiente dichas disposiciones no le serían aplicables}

Otro de los documentos que se encuentra en el archivo del nuncio Felici es un "parecer" enviado a Giuseppe Pizzardo, Secretario de la Sagrada Congregación para los Asuntos Eclesiásticos Extraordinarios, por el nuncio en Brasil, Alisi Masella, quien era el nuncio en Chile cuando se produjo la separación constitucional entre el Estado y la Iglesia, parecer que está fechado en diciembre de 1929 y se refiere a un posible concordato entre la Santa Sede y Chile en el que aborda principalmente a la personalidad jurídica de la Iglesia. En él recoge por escrito las ideas que había manifestado oralmente en una entrevista mantenida entre ambos prela$\operatorname{dos}^{43}$. Para el diplomático, el concordato podía ser de gran utilidad para la Iglesia: i) si se obtenía el perfecto reconocimiento de la personalidad jurídica de la Iglesia y de sus organismos, esto es, diócesis, parroquias, seminarios, etc.; ii) si en el mismo fuere reconocida a la Iglesia y sus organismos pleno derecho para adquirir, conservar, vender e hipotecar bienes sin permiso alguno del gobierno.

No obstante lo anterior, se preguntaba si podría llegar a firmarse un concordato con Chile, pregunta que respondía de inmediato con un es-

43 ASV. AES. Cile, 1928-1931. Pos. 285 P.O., fasc. 48. 
céptico "lo dudo bastante". Con todo, en las conversaciones con el gobierno debería: i) no ponerse en duda que el artículo constitucional relativo a la separación Iglesia-Estado reconoce la personalidad jurídica no solo a la Iglesia -lo que, en su opinión, no podía ponerse en duda- sino que, además, a las diócesis y parroquias; ii) sostener que en Chile, al menos hasta que no sea reformado el artículo 547 del Código Civil, la Iglesia es persona jurídica de derecho público; iii) sostener que sobre los bienes que la Iglesia poseía al momento de la promulgación de la nueva Constitución la Iglesia goza del más amplio derecho y que para los bienes adquiridos después de la promulgación de dicha Constitución y que adquiera en el futuro, "solo para el ejercicio del dominio (como se lee en al articulo constitucional relativo a la separación) y no para la misma adquisición del dominio está sujeta al derecho común" 44 .

¿Qué se entendía por derecho común? El diplomático no daba una respuesta a esta pregunta que él mismo se planteaba, sino que se remitía a lo que otros decían sobre el particular, sin dirimir la cuestión. Según algunos, si la Iglesia fuese una persona jurídica de derecho privado, podría sostenerse que el derecho común aplicable al solo ejercicio del dominio de los bienes de la Iglesia adquiridos después de la separación sería aquel que se refería a dichas personas jurídicas, de las que se ocupaba el título 33 del libro I del Código Civil. Otros, sin embargo, sostenían que, al menos mientras no se reformare el artículo 547 del Código Civil, la Iglesia continuaría siendo una persona jurídica de derecho público y por consiguiente dichas disposiciones no le serían aplicables.

\section{4) El Gobierno de Chile Y LA PERSONALIdAd JURÍdica DE LA IGLESIA EN LA CORRESPONDENCIA DEL MINISTERIO DE RELACIONES EXTERIORES}

En carta del ministro de Relaciones Exteriores, Conrado Ríos Gallardo, al embajador de Chile ante la Santa Sede, Ramón Subercaseaux, en julio de $1928^{45}$, es decir, dos meses después de que se conociese el proyecto de concordato presentado por el gobierno y el contraproyecto propuesto por el nuncio, le manifestaba que el borrador gubernamental había sido sometido a la consideración del ministro del Interior, Guillermo Edwards Matte, cuyo informe contenía numerosas observaciones, en su mayor parte fáciles de obviar, pero que mantenía una tesis capaz de afectar fundamentalmente los deseos del nuncio. Entendía el ministro del Interior que la Constitución había establecido que la Iglesia no gozaba de

\footnotetext{
44 "Solo per l'esercizio del dominio (come si legge nell'articolo costituzionale relativo alla separazione) e non per lo stesso acquisto di dominio sta soggetta al diritto comune”. Los subrayados son del original. ASV. AES. Cile, 1928-1931. Pos. 285 P.O., fasc. 48.

45 Ministerio de Relaciones Exteriores, Archivo General Histórico, Fondo Histórico, Santa Sede, vol. 1088 A, 1927-1931. El día de julio en que es escrita la carta no es legible.
} 
personería de derecho público sino en cuanto a los bienes que poseía al momento de adoptarse y que, respecto a los futuros, debía ser considerada como persona jurídica de derecho privado.

Agregaba el ministro al embajador que había oído extensamente al nuncio respecto a este punto, quien le había dado "razones muy inteligentes y dignas de ser consideradas para modificar el criterio del ministro del Interior", pero que él -el ministro de Relaciones Exteriores- no se había formado todavía una idea clara sobre esta dificultad. Con todo, la opinión del ministro del Interior le hacía fuerza, pues se basaba en los debates de la comisión constituyente, "que llegaron hasta Roma y que concluyeron, parece con el asentimiento de la Santa Sede, por dejar el punto en la penumbra sin estamparse bien claro en el texto de la Constitución”. Agregaba, sin embargo, el comentario de que Luis Claro Solar en su nueva obra sobre el Código Civil 46 interpretaba esta materia "en forma que no deja lugar a duda respecto a que la Iglesia es persona jurídica de derecho público". Concluía su carta, en lo que ahora me interesa, afirmando un tanto resignadamente, "y en este nivel nos encontramos, buscando el medio de salir del atajo sin que sufra la Iglesia en sus derechos ni se nos venga encima el elemento libre-pensador del Congreso".

Dos meses después, con fecha 30 de septiembre de $1928^{47}$, en una nueva carta que el ministro de Relaciones Exteriores enviaba al embajador de Chile ante la Santa Sede, Ramón Subercaseaux, le manifestaba lo sensible que era que el ajuste del concordato tropezase con dificultades y, peor aun, que dichas dificultades hubiesen ido en aumento, "al punto de que mis conversaciones sobre la materia con monseñor Felici, están, puede decirse, interrumpidas".

La razón de ello era "el problema de la personería juridica de la Iglesia" el que se había "hecho casi imposible de solucionar" porque algunos ministros, como el del Interior -Guillermo Edwards Matte- y el de Hacienda -Pablo Ramírez- estimaban que el artículo 10 de la Constitución establecía la personería de derecho privado para el ejercicio de los bienes que la Iglesia poseyere desde la fecha de la promulgación de la carta fundamental. Se fundaban para ello en la redacción misma del artículo, un tanto ambigua, que se debía a un acuerdo con el nuncio Masella, predecesor de Felici, según el cual no se habría querido, por consideraciones de respeto a la Santa Sede, emplear los términos precisos capaces de fijar, exactamente esa situación. Por su parte, agregaba el ministro, el nuncio Felici había expresado que el artículo referido era de tal modo claro, que no cabía discusión respecto de que reconocía a la Iglesia, la personalidad jurídica

\footnotetext{
46 Véase antes nota 23.

47 Ministerio de Relaciones Exteriores, Archivo General Histórico, Fondo Santa Sede, vol. 1088 A, 1927-1931.
} 
de derecho público, para lo cual no solo había hecho valer sus propios raciocinios, sino que también la opinión de algunos jurisconsultos como Luis Claro Solar.

Se encontraban en estas discusiones cuando se produjo un hecho que vino a complicarlas: el ministro de Hacienda envió al Congreso un proyecto de ley, que se encontraba firmado por el Presidente Ibáñez desde marzo de ese año, es decir, contemporáneo al inicio de las conversaciones sobre concordato, en el que se modificaban las disposiciones vigentes sobre impuestos a las herencias y legados, estableciendo, entre otros, un gravamen sobre los bienes heredados por los conventos y monasterios, conocidos bajo el nombre de "manos muertas". Para ello, el ministro había tenido que explicar el alcance y motivo de este nuevo impuesto que hasta ese momento no existía en Chile, para lo cual había entrado en consideraciones sobre el artículo 10 de la Constitución, interpretándolo como que la Iglesia tenía solo personalidad jurídica de derecho privado en Chile. Tal interpretación, incorporada en una ley de la República, podía decirse que interpretaba de manera oficial el alcance de la prescripción que debía de servir de base al concordato. Cuando el nuncio se impuso del citado proyecto "se molestó y, en una carta suya, un tanto violenta, me expresó sus sentimientos al respecto, después de haberlo hecho personalmente". El ministro llevó la cuestión al consejo de gabinete, "deseoso, siempre, de realizar mis intenciones con relación al concordato", pero encontró allí una atmósfera pesada, especialmente para el nuncio, por lo que le pareció más prudente no insistir. Es por lo que, en tan temprana fecha, el ministro consideró más prudente no insistir " $y$, dadas las circunstancias, estimo que, por ahora, más vale no mover este asunto", aunque el mismo ministro "más que nadie, reconozco las ventajas de un concordato, y, en consecuencia, deploro lo acaecido".

Medio año después, el 7 de marzo de 1929, en una nueva carta del ministro de Relaciones Exteriores al embajador ante la Santa Sede ${ }^{48}$ le manifestaba que los escollos surgidos no habían cambiado su concepto sobre la conveniencia del concordato, escollos que seguían refiriéndose a la personalidad jurídica de la Iglesia: "la dificultad producida estriba en la exigencia de que se puntualicen conceptos sobre la cuestión personalidad jurídica de derecho público [...] que van más allá de lo que la Constitución ha prescrito. Nuestra disposición es aceptar lo que la Constitución establece, sin entrar a interpretar o avanzar nada sobre lo que ella dispone acerca de tal punto, o sea, una fórmula que equivalga a no tocar la cuestión en el Concordato". La pretensión del gobierno era que se aceptara una fórmula que se refiriera simplemente a los conceptos de la Constitución o los reprodujera

48 Ministerio de Relaciones Exteriores, Archivo General Histórico, Fondo Santa Sede, vol. 1088 A, 1927-1931. 
textualmente, de manera que si así se hacía "habría desaparecido la dificultad que ha impedido adelantar las negociaciones que, en tal caso, tendría por mi parte mucho gusto en proseguir".

Ya sabemos que el nuncio entendía que no convenía insertar el texto del artículo constitucional en el concordato sino que solo cabía el reconocimiento, sin más, de la personalidad jurídica de la Iglesia. Las posiciones estaban claras para ambas partes, pero ninguna de las dos estaba dispuesta a ceder y eso fue lo que llevó estas negociaciones a su fin.

En efecto, en un oficio confidencial enviado por Miguel Cruchaga, del departamento diplomático del Ministerio de Relaciones Exteriores, al nuevo embajador de Chile ante la Santa Sede, de 2 de agosto de $1933^{49}$, Luis Eguiguren Valero, le adjuntaba un memorándum confeccionado por ese departamento sobre las negociaciones realizadas los años 1928 a 1930 entre la Santa Sede y la cancillería chilena destinadas a suscribir un concordato en el que aparecía claro que el tema de personalidad jurídica de la Iglesia había sido, finalmente, un escollo insalvable y la causa de que las conversaciones sobre el proyectado concordato llegaran a su fin.

Según dicho memorándum, la reforma que había introducido la Constitución a las relaciones entre el Estado y la Iglesia era lo suficientemente radical como para que tuviera múltiples consecuencias, dudas y dificultades en su aplicación práctica, por lo que, con el objeto de dejar en claro estas posibles situaciones dudosas, el gobierno había iniciado algunas gestiones destinadas a suscribir un concordato. Las conversaciones habían avanzado rápidamente, habiéndose llegado a solucionar definitivamente los diversos puntos que debían contemplarse en el futuro concordato. La principal dificultad, sin embargo, había sido "la diferencia de criterio para apreciar la situación que debia darse a la Iglesia en el convenio entre la Santa Sede y nuestro gobierno". Había sido este punto "de vital importancia el que paralizó las negociaciones y resultó ser un obstáculo infranqueable".

Si bien la Santa Sede había aceptado que se estampara en la Constitución el artículo que sancionó la separación Iglesia-Estado en la fórmula finalmente promulgada, había declarado que no sería posible obrar de la misma manera al tratarse de un concordato. Hacerlo, habría sido, en opinión del nuncio que se recogía en el memorándum, que la Iglesia se consideraba como persona jurídica de derecho privado. Siendo ella persona jurídica de derecho público, no podía reconocer en un concordato que era persona jurídica de derecho privado.

El gobierno, por su parte, estimaba que cuando la Constitución hablaba en su artículo 10 de "derecho común", había querido referirse al

49 Ministerio de Relaciones Exteriores, Archivo General Histórico, Fondo Santa Sede, vol. 1367 A, 1934. 
derecho común en materia de persona jurídica, dando ese nombre a aquellas que no tenían el carácter especial de personas jurídicas de derecho público, "de modo que, en cuanto al ejercicio del dominio de los bienes futuros, la Iglesia, constitucionalmente hablando, es persona jurídica de derecho privado". En el curso de la discusión sobre este punto, el gobierno había aceptado que la Iglesia era persona de derecho público y reconoció como personas de derecho público "a todas las instituciones monásticas canónicamente constituidas", las que podían instalarse en Chile sin necesidad de los trámites que se exigían para la formación de personas de derecho privado. También había reconocido el gobierno chileno que los bienes adquiridos con anterioridad a la promulgación de la Constitución de 1925 pertenecían a una persona jurídica de derecho público y que, consecuencialmente, podían ser enajenados e hipotecados sin intervención alguna del Congreso.

El único punto sobre el cual había sido imposible llegar a un acuerdo había sido la situación de la Iglesia con relación al ejercicio del dominio de los bienes futuros. La Santa Sede había declarado que no podía aceptar, en un concordato, la única obligación que se le imponía, es decir: pedir la autorización del Congreso para vender, hipotecar o donar. El memorándum terminaba con una frase que suena lapidaria: "no pudiéndose salvar esta única dificultad, las negociaciones se suspendieron a fines de 1930".

\section{5) LA ACTIVIDAD POSTERIOR DEL NUNCIO}

Llegadas a su fin las conversaciones sobre un concordato a fines de 1930 por decisión del gobierno de Chile, en los años siguientes el nuncio siguió preocupado del tema, recabando nuevos informes, pero no se volvieron a retomar dichas tratativas, aunque la Santa Sede siguió con su política concordataria, celebrando nuevos acuerdos. Las graves aprensiones del nuncio, sin embargo, fueron pronto mitigadas por la misma legislación chilena, pues, poco después, la ley 5.020, de 30 de diciembre de 1931 reemplazó el artículo 556 del Código Civil, por otro más breve que se limitaba a sentar el principio de que "las corporaciones pueden adquirir bienes de todas clases a cualquier título". Se dejaba vigente el paso inicial del primero de los incisos del primitivo artículo 556, pero se derogaban la exigencia de obtener el permiso de la legislatura para conservar la posesión de los bienes raíces que adquirieran (inc. $1^{\circ}$ ) y la obligación de enajenarlos en el evento de no obtener dicho permiso (inc. $2^{\circ}$ ). Subsistían, sin embargo, las limitaciones para su enajenación, establecidas en el artículo 557, para cuya derogación habría que esperar todavía algunos 
$a_{n} s^{50}$. Pero desaparecía una de las preocupaciones del diplomático vaticano.

Cuando el 20 de abril de 1938 Ettore Felici fue enviado como nuncio a Yugoslavia, donde le esperaba la terrible experiencia de la invasión nazi, el nuncio salió de nuestra patria sin haber logrado lo que había sido para él un anhelo muy sentido: haber dejado en claro el tema de la personalidad jurídica de derecho público de la Iglesia. La vida se encargaría de hacerlo.

\section{CONCLUSIONES}

Llegado al término de estas páginas, podemos sintetizar su contenido en las conclusiones que siguen:

1. El inicio de las gestiones diplomáticas del nuncio Ettore Felici en Chile en los primeros días de 1928, se produjo cuando el papa Pío XI, elegido el 6 de febrero de 1922, había iniciado una política concordataria que había llevado a la firma de diversos documentos internacionales, algunos de los cuales se habían concluido en los meses inmediatamente anteriores. Todo ello sucedía cuando aun no se habían concluido los pactos de Letrán que crearían el Estado de la Ciudad del Vaticano, lo que ocurriría el 11 de febrero de 1929.

2. Entre las instrucciones que le fueron entregadas al nuncio Felici en Roma, estaba la de gestionar la posibilidad de un concordato entre Chile y la Santa Sede, instrucción que se situaba y era congruente con la política concordataria general que llevaba adelante el pontífice reinante.

3. Una vez que el nuncio presentó sus credenciales, no tardó en poner manos a la obra, para lo cual hizo entrega al gobierno de Chile, por mano del subsecretario de Relaciones Exteriores, del concordato celebrado semanas antes entre la Santa Sede y el gobierno de la República de Letonia, que sería usado de modelo y al que seguiría de cerca en no pocos de los artículos del proyecto que el mismo gobierno se encargó de redactar. Por su parte, el embajador de Chile ante la Santa Sede había hecho llegar al gobierno el concordato celebrado con el gobierno de Polonia en 1925 que también inspiraría algunas de las disposiciones del concordato que se preparaba.

4. Desde el primer momento dos fueron los temas que se presentaron como fundamentales en las conversaciones que se llevaron adelante: la designación de los obispos y la personalidad jurídica de derecho público de la Iglesia, tema que había empezado a ser controvertido con la entrada en vigencia de la nueva Constitución de 1925 que había sancionado constitucionalmente la separación entre el Estado y la Iglesia. Es por lo

Ley 7.612, de 21 de octubre de 1943. 
que el tema de la personalidad jurídica de la Iglesia, más que el tema de la designación de los obispos, ocupó un lugar no menor en la correspondencia del nuncio con la Santa Sede.

5. Los concordatos que sirvieron de modelo al gobierno, especialmente los de Polonia y de Letonia reconocían la personalidad jurídica de la Iglesia y su capacidad para adquirir, administrar y enajenar toda clase de bienes, pero no le reconocían la calidad de persona jurídica de derecho público. Puesto que el tema era controvertido en Chile, el gobierno, aprovechando el texto de dichos concordatos, hizo lo mismo en el proyecto que preparó, en el que, si bien reconocía la capacidad de la Iglesia para adquirir, administrar y enajenar bienes, guardaba silencio en cuanto a la calidad de su personalidad jurídica y nada decía en relación a que fuera de derecho privado o público.

6. Como el nuncio advirtiera esta deficiencia en el proyecto gubernamental, y otras que no vienen ahora al caso, aprovechando la invitación del gobierno de formular observaciones al proyecto, presentó un contraproyecto completo en el que se afirmaba contundentemente la personalidad de derecho público de la Iglesia.

7. Pero no era el nuncio quien debía llevar adelante las negociaciones para la firma de dicho texto, sino que ellas eran llevadas directamente entre Roma y Santiago, por lo que la tarea asumida por el nuncio fue ilustrar a sus superiores vaticanos sobre la discusión que se desarrollaba en Chile y acerca de la importancia de que el futuro concordato no ofreciera dudas acerca de este tema.

8. La posición del gobierno era que el artículo 10 de la Constitución establecía la personería de derecho privado para el ejercicio de los bienes que la Iglesia poseyere desde la fecha de la promulgación de la carta fundamental. Se fundaban para ello en la redacción misma del artículo, redacción un tanto ambigua, que se debía a un acuerdo con el nuncio Aloisi Masella, predecesor de Felici, según el cual no se habría querido, por consideraciones de respeto a la Santa Sede, emplear los términos precisos capaces de fijar, exactamente esa situación.

9. El tema era de primera importancia para el nuncio y el momento de dirimirlo era el concordato que se preparaba, razón por la que buscó el parecer de diversos juristas, los cuales, por lo general, se situaban en una línea diferente a la del gobierno.

10. Para Claro Solar, era indudable que la Iglesia seguía siendo persona jurídica de derecho público a todo evento. Alessandri tuvo la aproximación más original a la duda surgida con la nueva Constitución, entendiendo que el problema era de retroactividad de la ley, por lo que, aplicando las reglas de la ley respectiva, entendía que el arzobispado de Santiago seguía siendo persona jurídica de derecho público, personalidad de la que la nueva Constitución no lo había privado. Pero su respuesta se limitaba solo al arzobispado de Santiago, cuya existencia era anterior in- 
cluso a la República. ¿Qué pasaba con los nuevos obispados que se erigieran después de 1925? Alessandri no tocaba el tema.

Con todo, supuesto que dicha personalidad pública subsistía después de 1925, respecto del uso de los bienes adquiridos a partir de 1925, sin dejar de ser persona jurídica de derecho público, debía someterse al derecho común, solución que era compartida con otros juristas.

11. Había, sin embargo, quien, como Miguel Valdés, entendía que a partir de 1925 la Iglesia había perdido su calidad de persona jurídica de derecho público y debía organizarse como persona jurídica de derecho privado, salvo en lo relativo a los bienes adquiridos antes de 1925 respecto de los cuales podía actuar sin limitación alguna.

12. Llama la atención que la discusión en torno a la personalidad jurídica de la Iglesia surgiera a propósito de un artículo de la nueva Constitución que no pretendía definir el tema de la personalidad jurídica de la Iglesia, al menos expresamente. Las opiniones eran contestes en que se trataba de un artículo de redacción poco clara, la que, como se insinúa en algunos informes, habría sido expresamente buscada.

13. La preocupación del nuncio se mantuvo permanentemente, y ella explica sus esfuerzos por dejar en claro ante sus superiores romanos la necesidad de que se reconociese expresamente la personalidad de derecho público de la Iglesia, su inquietud ante el rumor de que Roma estaría dispuesta a no insistir en dicha personalidad y su negativa a que en el proyectado concordato se reprodujese el artículo de la Constitución que declaraba la libertad de cultos, cuya oscura redacción era la causa de las dificultades que se estaban presentando tanto a nivel interpretativo como práctico.

14. La oposición del diplomático vaticano a cualquier modalidad diversa al reconocimiento total de la personería pública de la Iglesia fue definitiva, como fue también definitiva la posición del gobierno que, aun reconociendo la personería pública de la Iglesia antes de 1925 y la consecuencia que de ello se derivaba para su patrimonio, entendía que dicho estatuto había cambiado con la nueva Constitución por lo que, en cuanto al ejercicio del dominio de los bienes futuros, la Iglesia, constitucionalmente hablando, era persona jurídica de derecho privado. Las posiciones eran incompatibles y ninguna de las partes quiso ceder en sus planteamientos lo que significó no solo el fracaso de la posibilidad de solucionar la diferencia por medio de un concordato, sino el fracaso de la posibilidad misma de un concordato.

\section{BIBLIOGRAFÍA CITADA}

Archivio Segreto Vaticano, Sacra Congregazione degli Affari Ecclesiastici Straordinari, Cile 1927-1928. Pos. 283-285 P.O., Fasc. 
47; 1928-1931, Pos. 285 P.O., Fasc. 48; Nunziatura Apost. di Cile, Archivio di mons. Ettore Felici, nuncio apostolico, pos. $1^{\mathrm{a}}, 3^{\mathrm{a}}, 4^{\mathrm{a}}$.

Claro Solar, Luis (1927) Explicaciones de derecho civil chileno y comparado, V: De las personas. Santiago: Imprenta Cervantes, $611 \mathrm{pp}$.

De la Brière, Y. (1942) "Les concordats postérieurs à la Grande Guerre". En Dictionnaire de droit Canonique. Paris: Tomo III, cols. 1431-1472.

Enchiridion dei concordati. Due secoli di Storia dei Rapporti Chiesa-Stato (2003). Bologna: Dehoniane, 2257 pp.

Ministerio de Relaciones Exteriores, Archivo General Histórico, Fondo Histórico, Santa Sede, vols. 1088 A, 1927-1931; 1367 A, 1934.

Minnerath, Roland (2012) L'Église catolique face aux États. Deux siècles de pratique concordataire 1801-2010. Paris: Les Éditios du Cerf, 650 pp.

Salinas Araneda, Carlos (2012) "Un primer proyecto de concordato entre Chile y la Santa Sede en 1928". Revista Chilena de Derecho, vol. 39, No 3, pp. 665-698.

Salinas Araneda, Carlos (2014) "El tercer proyecto de concordato entre Chile y la Santa Sede en 1928. Texto y comentario". Revista de Derecho de la Pontificia Universidad Católica de Valparaíso, vol. 42, No 1, pp. 555-595.

Salinas Araneda, Carlos (2014) "Crónica de la tramitación de un proyecto de concordato entre Chile y la Santa Sede en 1928". Revista de Estudios Histórico-Jurídicos, vol. 36, pp. 483-512.

Stella, Giordano (2009) Pio XI il Papa dei concordati. Milano: Gribaudi Editore, $240 \mathrm{pp}$.

Valencia Avaria, Luis (1986) Anales de la República. 2a edición. Santiago: Editorial Andrés Bello, Tomo I, 736 pp. 